\title{
"A semente de uma grande cidade": uma leitura dos discursos construídos sobre a fundação da cidade de Ponta Grossa (PR)
}

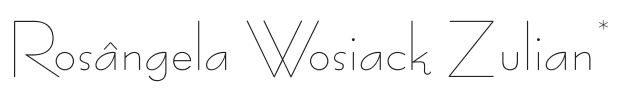

O processo de construção discursiva de uma cidade passa pelos projetos sobre ela elaborados. Conforme Schorske $^{1}$, não se pensa a cidade em isolamento hermético, mas forma-se uma imagem dela por meio de um filtro da percepção derivado da cultura herdada e transformado pela experiência pessoal. Ou seja, o olhar sobre a cidade passa pela forma de vê-la e por quem a vê.

Longe de ser percebida como simples dado ou cenário, ela é aqui entendida como um espaço em construção, onde se busca captar os processos e operações dessa ordem representativa, como progresso e modernização. Adotamos a perspectiva de cidade como

[...] um conjunto de trocas no tempo e no espaço, local de disputa de diferentes projetos, enfim como um cenário vivo e dinâmico, em que se associam e alternam elementos de permanência e ruptura, confluentes no mesmo caudal, no mesmo "ethos". Palco do grande enredo social e cultural que se expressa em manifestações identitárias, a cidade delineia as nuanças do processo de consolidação de uma nova urbanidade. Ela surge como um produto das vivências, da solida-

\footnotetext{
Doutora em História Cultural pela Universidade Federal de Santa Catarina e professora adjunta do Departamento de História da Universidade Estadual de Ponta Grossa.

${ }^{1}$ SCHORSKE, Carl E. Pensando com a História: indagações na passagem para o modernismo. São Paulo: Companhia das Letras, 2000, p. 53. 
riedade, dos valores e das tensões, atravessada por múltiplos

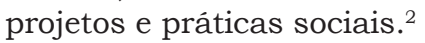

Almejando construir a imagem de um "novo" Paraná tanto as elites campeiras quanto as intelectuais republicanas recriaram a cidade de Ponta Grossa dentro de seus projetos e valores, e elaboraram sobre ela um discurso que a representava como um espaço ordeiro, moderno e progressista. As representações construídas buscavam legitimar suas origens, pois "a idealização das recordações também transforma o passado coletivo" criando-se, a favor do ontem, um mito fundador.

Marilena Chauí, ao discutir a construção mítica da nação brasileira, coloca-a no nivel das representações homogeneizantes que os brasileiros fazem do país e de si mesmos. Essa representação permite, em certos momentos, crer na unidade, na identidade e na indivisibilidade da nação e do povo brasileiros e, em outros, perceber a divisão social e política sob a forma dos amigos da nação e dos inimigos a combater, "combate que engendrará ou conservará a unidade, identidade e indivisibilidade nacionais. ${ }^{4}$ "

Para a autora, a idéia de mito é tomada não apenas no sentido etimológico de narração pública de feitos lendários da comunidade (no sentido grego da palavra mythos), mas também no sentido antropológico, como narrativa que traz uma "solução imaginária para tensões, conflitos e contradições que não encontram caminhos para serem resolvidos no nivel da realidade". O mito também pode ser interpretado no campo psicanalítico, "como impulso à repetição de algo imaginário, que cria um bloqueio à percepção da realidade e impede de lidar com ela". ${ }^{5}$

${ }^{2}$ DITZEL, Carmencita de Holleben Mello. Manifestações Autoritárias. O integralismo nos Campos Gerais (1932-1955). Florianópolis: UFSC, 2004- Tese (Doutorado em História), pp.50-60.

${ }^{3}$ LE GOFF, Jacques. A Civilização do Ocidente Medieval. v. 1. Lisboa: Ed. Estampa, 1983 , p. 15.

${ }^{4}$ CHAUI, Marilena. Brasil: mito fundador e sociedade autoritária. São Paulo: Ed. Fundação Perseu Abramo, 2000, pp. 7-8.

${ }^{5}$ Ibidem, p. 9. 
No caso, a palavra mito, mesmo que se refira a acontecimentos considerados históricos, está sendo empregada num sentido amplo. A razão, entre outras, é que essas construções históricas, feitas em grande parte por líderes participantes dos acontecimentos, têm sempre um caráter "interessado", omitindo certos aspectos, dando ênfase a outros, em suma, construindo socialmente a sua versão.

Mitos fundadores geram imaginários e são gerados por eles, reforçando a cada passo uma narrativa "inventada", produtora de sentidos. Nos relatos sobre a fundação da cidade de Ponta Grossa essas questões estão presentes, "invenções históricas e criações culturais" ${ }^{6}$ que tramam o épico e o sagrado, na construção de um momento inicial.

Flávio Carvalho Guimarães, jornalista, senador da república e membro da elite campeira local escreveu, em 1921, um texto jornalístico no qual dava a sua versão da gênese da cidade, na tentativa de ratificar, para seus habitantes, a idéia de um espaço especial e diferente dos demais. Das diversas versões existentes, a de Flávio Carvalho Guimarães, de forma singular, traz essa "solução imaginária" para as tensões e os conflitos presentes, com o intuito do apagamento das contradições que não puderam ser resolvidas ou sequer explicitadas. Transcrevemos o artigo na integra, destacando as passagens que significam essa construção discursiva.

Não se fez, ainda, a completa luz histórica acerca do impressionante e belíssimo modo por que se fez a escolha do local para a cidade de Ponta Grossa. A não ser o eco das testemunhas oculares, que foram transmitindo aos filhos e netos toda essa história tecida de magnificos ensinamentos, não conheço outras provas, orientadoras de uma pesquisa segura que me pudessem levar à certeza plena da veracidade do fato. Em todo caso, os leitores ficarão conhecendo esse enredo de ouro, em cuja narração há exemplos úteis e largos descortinos de ideal que hoje são virtudes adormecidas, quase que abandonadas pela nossa nacionalidade, irrequieta e travessa em seus devaneios de patriotismo.

\footnotetext{
${ }^{6}$ Ibidem, p. 57. 
No largo trecho que separa os serenos rios Tibagi e Pitangui, agitaram-se um dia os habitantes dessa região tranqüila, a fim de que, unidos, pudessem escolher o melhor ponto onde pudessem trabalhar, com o espírito de coesão e solidariedade, impulsionando o progredir coletivo em uma intima harmonia e fecunda congregação de esforços. Reunidos nessa doce assembléia rude, houve, como é natural, as mais fundas divergências, porque não só lhes tocava, de perto, o interesse material, como também se via o anseio de que fosse vitoriosa a opinião deste ou daquele grupo. Quando estavam a explodir, quando tudo estava inteiramente perdido e a solução pronta do problema se emaranhava às paixões exaltadas, perturbadoras da paz e da serenidade reinante no meio ambiente, apareceu, por último, uma interessantíssima fórmula, que foi a conciliadora dos choques de idéias e dos antagonismos.

Ei-la: em um claro dia de sol, em que o céu se achava inteiramente azul, limpo de nuvens, soltaram um pombo branco, debaixo do qual subiam os gritos e os aplausos de toda aquela gente, presa de estranho delírio. O olhares curiosos fixaram-se na ave que voava indecisa, em largas curvas, ora se arrastando à terra, ora pairando mais alto, galgando o espaço, asas abertas, no largo, luminosos e melancólico silêncio do dia.

Os corações daquela aglomeração rude batiam de prazer e de susto, pois concluído ficara que, no lugar onde o pombo pousasse, se ergueria, como veio a se erguer, a cidade de Ponta Grossa. E o juiz da discórdia, na carícia infinita do ar, divertia-se, do alto, a olhar aquela gente, que não o perdia de vista, inteiramente atônita, à espera do julgamento final. Depois, voou em linha reta. Os nossos habitantes, olhos pregados no "juiz", acompanhavam-no, ébrios de emoção. Passa um frio, gelando as almas e os grupos, e em todos os olhares febris de ânsia estava escrita a suave interrogação: qual o grupo vitorioso?

O pombo pousou o vôo. Correm, cheios de espanto. E irrompem gritos de alegria que vão ao delírio, palmas, longos abraços, gauchadas febris. O espetáculo era, para eles, empolgante. Sobre uma cruz esquecida e velha, abandonada, solitária, sem lágrima e sem prece, com os braços cansados de silêncio e abertos às mágoas das almas que por ali transitavam, o carinhoso pássaro pousou. E, exausto da via- 
gem, contemplava, na doce macieza de suas penas brancas, banhadas de ouro, o fim pacífico de uma luta que ameaçava, destruidora dos sagrados interesses da comunhão.

Nesse dia, aqueles homens começaram o trabalho de união mais intima em prol de seus ideais de coesão e harmonia e, com fé, lançaram a semente de uma grande cidade, nascida e formada aos beijos da paz e aos raios do mais fraternal litigio que hei conhecido em minha vida.

Magnífica página, em que esplende a grande honra de uma tradição tão linda quanto cheia de ensinamentos profícuos, para todos os que têm a responsabilidade de velar pelos nossos destinos. História rude, de uma simplicidade encantadora, mas incontestavelmente maravilhosa. Simplesmente maravilhosa. ${ }^{7}$ [sem grifo no original]

Flávio Carvalho Guimarães tentou localizar os acontecimentos numa unidade coerente, que incluía o passado, o presente e o futuro, ordenando a história. ${ }^{8}$ Ao vincular fundadores e governantes contemporâneos a ele, buscou conferir sentido e plausibilidade não apenas à escolha do local, mas também às formas de organização mental e política das elites, as quais ele integrava, explicando à sua maneira a ocupação do poder local.

A conformação da sociedade dos Campos Gerais do Paraná ${ }^{9}$ está relacionada ao desenvolvimento de atividades

\footnotetext{
${ }^{7}$ MONTES, David Pilatti. Flávio Carvalho Guimarães. In: Antologia. Academia de Letras dos Campos Gerais. Ponta Grossa, 2002, pp. 137-138. Embora o autor do artigo não cite a fonte, afirma que o mesmo foi escrito em $1921 \mathrm{em}$ forma jornalística. Esse mito fundador compõe o imaginário local, com algumas variáveis. Uma delas diz que os povoadores, descontentes de viver longe dos beneficios da religião, resolveram, em memorável assembléia, dar os primeiros passos para a fundação da freguesia e construção da capela definitiva. Como não chegassem a um acordo quanto ao local do templo, soltou-se um casal de pombos (ou um pombo doméstico da fazenda de Miguel da Rocha Carvalhaes). O local onde as aves pousaram, possivelmente uma figueira secular no alto da colina central da cidade, teria sido o escolhido para a capela.

${ }^{8}$ BERGER, Peter L.; LUCKMANN, Thomas. A construção social da realidade. Petrópolis: Vozes, 1985, pp. 140-141.

${ }^{9}$ A denominação "Campos Gerais" data de 1638, quando Artur de Sá e Menezes, Governador do Rio de Janeiro, escreveu ao Rei de Portugal informando sobre a descoberta de um caminho para as minas de Cataguazes: "...agora segue-se a utilidade dos Campos Gerais, os quais são tão ferteis para os gados que dizem 
econômicas ligadas ao transporte, comércio e criação de animais entre as regiões do sul do país, tendo em vista o abastecimento de São Paulo e das regiões mineradoras do século XVIII. A região, que possibilitava o trânsito de pessoas e animais, tornou-se rota obrigatória para os "tropeiros". ${ }^{10}$

O Caminho das Tropas ou Caminho do Viamão viabilizou uma ocupação mais consistente do interior do território paranaense sinalizando, assim, uma nova perspectiva econômica: as fazendas de criação e o comércio das tropas de muares, atividades ao mesmo tempo distintas e relacionadas, marcaram a fisionomia dos Campos Gerais. Esta região, além do intenso trânsito e comércio, viu florescer um considerável número de fazendas e de pousos de tropas, muitos dos quais se tornaram vilarejos e mais tarde cidades. Esses agrupamentos funcionavam como pontos de convergência para as sociabilidades das populações fazendeiras, ligadas, direta ou indiretamente, por um sistema de caminhos.

Uma certa vida urbana se implantaria então, nos séculos XVIII e XIX, nas localidades da Lapa, Palmeira, Ponta Grossa, Castro e Jaguariaiva inicialmente. Uma vida urbana centrada na administração, na religião e no pequeno comércio

estes homens, virão a ser outra Buenos Aires porque para a parte sul confinam com os caminhos da Nova Colônia e para a parte norte". LANGE, Francisco Lothar Paulo. Os Campos Gerais e sua Princesa. Curitiba: Copel, 1998, p. 108. Para os fins deste trabalho adotamos a perspectiva do Dicionário Histórico e Geográfico dos Campos Gerais, cuja definição procura preservar os critérios naturais e históricos de identidade regional e que, ao mesmo tempo, seja funcional diante das tendências recentes de organização do espaço. Os critérios de homogeneidade foram: $1^{\circ}$ ) Fitogeografia: a vegetação primitiva do município deveria ter sido, no todo ou em parte, de Campos Limpos. $2^{\circ}$ ) Tropeirismo: o município deveria ter estado integrado ao "Caminho de Viamão", principal rota das tropas no século XVIII e XIX. $3^{\circ}$ ) Associativismo: o municipio deve integrar a Associação dos Municipios dos Campos Gerais (AMCG). Disponivel em www.uepg.br/dicion/ campos_gerais.htm.

10 "Todo e qualquer viajante, comerciante ou aventureiro que se dirigisse por terra de São Paulo para o extremo sul do país, e vice-versa, no final do século XVIII e nos inícios do século XIX, deveria passar pelo bairro de Ponta Grossa, nas terras da Comarca de Castro, à época, local obrigatório de passagem, pois ligado ao Caminho do Viamão". PINTO, Elisabete Alves; GONÇALVES, Maria Ap. Cezar. Ponta Grossa: um século de vida (1823-1923). Ponta Grossa: Kugler, 1983, p. 17. 
da região, onde os fazendeiros vão apenas em momentos especiais. ${ }^{11}$

Para Oliveira, a presença dos índios kaingang somada às freqüentes requisições, pela Coroa, de homens e bens para as guerras contra os castelhanos no sul, ou seja, as necessidades de ataque e defesa do território propiciaram a conformação de uma elite fundiária militarizada, "com um estilo de vida e mando adequados aos valores da violência e da conquista". ${ }^{12}$

Isaia, ao trabalhar a formação histórica do Rio Grande do Sul, comenta que tanto a atividade da presa do gado quanto o caráter da região fronteiriça plasmaram um homem característico, portador de valores próprios e de uma forma de vida peculiar. A constante tensão da vida sulina, sujeita às infindáveis disputas na fronteira, evidenciariam um tipo humano capaz de enfrentar as vicissitudes de uma época de incertezas. ${ }^{13}$ Salvas as devidas especificidades, pode-se dizer que o mesmo se passou na região dos Campos Gerais. Embora pouco documentados, relatos esparsos de situações de disputa pela posse da terra sugerem um aparato de violência, que inclui bandos armados sob o comando de grandes proprietários, assassinatos e julgamentos que não penalizavam os culpados. É o que relatou Salvador Correa Coelho ao publicar em 1869 suas impressões sobre uma viagem feita à região:

Pellos anos 1833, 1834, achou-se [a cidade de] Castro implicado em furiosas intrigas de famílias importantes da localidade; appareceu a vendetta corsa; o punhal e o bacamarte do assassino tiveram livre exercício até nas praças publicas! Muitos expatriaram-se por causa dos distúrbios, e a povoação, que ostentou tam grande immoralidade e insegurança

\footnotetext{
${ }^{11}$ OLIVEIRA, Ricardo Costa de. O silêncio dos vencedores: genealogia, classe dominante e Estado no Paraná. Curitiba: Moinho do Verbo, 2001, p. 97.

${ }^{12}$ Idem.

${ }^{13}$ ISAIA, Artur Cesar. Catolicismo e autoritarismo no Rio Grande do Sul. Porto Alegre: EDIPUCRS, 1998,pp. 29-30.

110 Revista de História Regional 14(2): 104-126, Inverno, 2009
} 
individual, por longo tempo ressentiu-se das suas consequências $[\ldots]^{14}$

Nessa perspectiva, a sociedade dos Campos Gerais é semelhante à das demais regiões campeiras e sertanejas do sul do país. Os habitantes, até a chegada dos primeiros imigrantes, eram majoritariamente de ascendência lusa: bandeirantes paulistas, curitibanos, parnanguaras, com fortes contatos comerciais e sociais com o Rio Grande do Sul. Coelho, como muitos cronistas da época, registrou essa circularidade:

Os paranaenses viajam armados, como os povos da província de S. Pedro, cujos costumes em muitíssimos pontos são similhantes (sic) pois não fallando no traje que é o mesmo, no modo d'exprimir o seu pensamento são como os d'aquella provincia, adoptando palavras hespanholas em suas conversas. Os povos que se communicam frequentemente para logo participam da influencia mutua da linguagem. ${ }^{15}$

Tais trocas culturais consolidaram um estilo de vida campeiro, ao mesmo tempo agressivo e defensivo, com seus costumes, vocabulário, vestimentas, e um caráter guerreiro e arredio às práticas religiosas, limitadas a batizados, casamentos, exéquias e à reza de ladainhas.

Desta forma, pode-se dizer que, desde a época dos primeiros povoadores até o final do século XIX, quando se completou a expansão fazendeira sobre a totalidade dos campos do Paraná, a sociedade apresentou a mesma estrutura social que caracterizou a formação brasileira, em que predominava a relação senhor-escravo. "Nem o objeto da exploração econômica, nem o ambiente geográfico, nem outro fator qualquer, afetou a estrutura tradicional, até o final do século XIX”. ${ }^{16}$

Sobre a base da grande propriedade de terras de campo natural, da criação de gado, do tropeirismo e da invernagem, e do trabalho escravo de índios e negros, caracterizou-se no

${ }^{14}$ COELHO, Salvador José Correa. Passeio a minha terra. s.d.

15 Ibidem, p. 68.

${ }^{16}$ MACHADO, Brasil Pinheiro. Três cadernos de História: idéias e reflexões. Curitiba: Arte e Letra, 2002, p. 72. 
século XIX, a classe dominante regional, configurada em familias fazendeiras, vivendo em suas terras e detendo o poder político local e regional, por meio de oligarquias parentais. É nesse período que florescem as cidades dos planaltos paranaenses: Castro, Ponta Grossa, Palmeira, Lapa, Guarapuava, Palmas, todas elas nos roteiros das tropas, das fazendas, das invernadas. ${ }^{17}$

Na elaboração de Flávio Carvalho Guimarães, o ponto de partida é a concepção de história como um ensinamento e um exemplo da necessidade de coesão e harmonia num momento tão decisivo como foi o da fundação da cidade. Em seguida, aparece a idéia de documento como prova da "verdade dos fatos" que ele não possui. No entanto essa prova poderia ser substituída pelo testemunho daqueles que fidedignamente repassaram o que viram às gerações seguintes.

Tal relato tem a intenção de despertar "virtudes adormecidas" pela inquietude nacionalista e patriótica. O autor escreveu o artigo em 1921, momento de emergência de diferentes projetos no país, momento de intenso debate sobre a nação brasileira, às vésperas de completar cem anos de vida independente. Divergindo sobre os motivos do descompasso do país com a modernidade e sobre os caminhos que deveriam conduzir a ela, a intelectualidade brasileira convergia, no entanto, à compreensão de que o centenário seria o momento-chave em que tais questões deveriam ser discutidas.

Flávio Carvalho Guimarães não deveria ignorar essa efervescência de "nossa nacionalidade irrequieta e travessa em seus devaneios de patriotismo". No entanto, reduziu o campo de análise ao largo trecho que separa "os serenos rios Tibagi e Pitangui" e coloca sua reflexão a serviço dos interesses dos grandes proprietários quando invoca uma "interessantíssima fórmula, que foi a conciliadora dos choques de idéias e dos antagonismos".

Destacou o autor que a harmonia foi quebrada quando diferentes grupos disputavam o local-marco do povoamen-

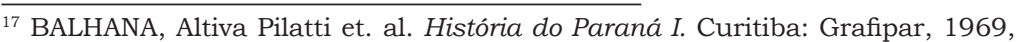
p.65.

112 Revista de História Regional 14(2): 104-126, Inverno, 2009
} 
to - a capela. Guimarães usou expressões como "paixões exaltadas", "quando tudo estava perdido", "as mais fundas divergências", sugerindo a existência de conflitos, contemporâneos ou anteriores à sua fala. Talvez evocasse os aborrecimentos a que eram submetidos os moradores do Bairro (de Ponta Grossa) quanto tinham que percorrer continuamente a distância de sete léguas até a vila de Castro para resolver questões particulares ou oficiais. Talvez sugerisse que naquele momento o Bairro já apresentava recursos suficientes, econômicos e humanos, para tomar as rédeas de sua própria vida política e que o tempo da emancipação chegara.

É possivel inferir que o local da fundação não era o único motivo da discordância e, mesmo que o fosse, Guimarães não questionou o fato de que Miguel da Rocha Carvalhais, outro grande proprietário e um dos dirigentes do Bairro, aparecesse sempre em primeiro lugar entre os nomes associados aos dos primeiros fundadores, "moço com alguma ilustração, pertencente à família tradicional, dispondo de recursos" ${ }^{18}$. Parece estar subjacente aí a disputa pelo poder político local, resolvida nesse dia, quando aqueles homens começaram com "o trabalho de união mais intima em prol de seus ideais de coesão e harmonia".

O "juiz" da questão, aquele que trouxe a solução para os choques de idéias e os antagonismos, era símbolo da comunicação com o invisível, "um signo vindo do passado ou dos céus, carregando uma significação com conseqüências presentes e futuras". ${ }^{19}$ A figura do pombo ${ }^{20}$, no caso, funcionou como um semióforo, ou seja,

[...] um signo [...] para indicar algo que significa alguma outra coisa e cujo valor não é medido por sua materialidade e sim por sua força simbólica. [...] é, pois, um acontecimento, um animal, um objeto, uma pessoa ou uma instituição retira-

\footnotetext{
18 NOVAES, Pedro. A fundação de Ponta Grossa. Prefeitura Municipal de Ponta Grossa: Impressora Pontagrossense, 1943, pp. 22-23.

${ }^{19}$ CHAUI, Marilena. Brasil ..., Op. cit., p. 12.

${ }^{20} \mathrm{O}$ pombo, como simbolo do mito fundador, tem forte significado para a cidade: sua figura está estampada na bandeira do município e em quase todas as imagens oficiais.
} 
dos do circuito do uso ou sem utilidade direta e imediata na vida cotidiana porque são coisas providas de valor simbólico, capazes de relacionar o visivel e o invisivel, seja no espaço, seja no tempo, pois o invisivel pode ser o sagrado (um espaço além de todos os espaços) ou o passado ou o futuro distantes (um tempo sem tempo ou eternidade) e expostos à visibilidade, pois é nessa exposição que realizam sua significação e sua existência. ${ }^{21}$ (sem grifo no original)

A delicada construção da imagem e do vôo da ave, pousando "sobre uma cruz esquecida e velha, abandonada, solitária, sem lágrima e sem prece", fortalece a idéia da união entre fundação de um espaço urbano e religiosidade, representando o "fim pacífico de uma luta que ameaçava, destruidora dos sagrados interesses da comunhão". Sob os signos do sagrado, a cruz e a ave da paz, Guimarães escamoteou os conflitos, superados em prol de um "bem maior".

A argumentação de Flávio Carvalho Guimarães foi elaborada em torno da demarcação de um espaço, não apenas geográfico, mas de poder, velada pela justificativa religiosa. O problema que se emaranhava às "paixões exaltadas" nada mais era que a eufemização dos interesses e da violência que engendraram a delimitação dos espaços de poder dos proprietários locais.

A noção de espaço contém em si o princípio de uma apreensão relacional do mundo social: toda a "realidade" que designa reside na exterioridade mútua dos elementos que a compõem. Desta forma, indivíduos ou grupos existem e subsistem na e pela diferença, isto é, pela posição que ocupam em espaços de relações. Embora esse princípio de diferenciação varie no tempo e no espaço, pode-se dizer que

[...] todas as sociedades se apresentam como espaços sociais, isto é, estruturas de diferenças que não podemos compreender verdadeiramente a não ser construindo o princípio gerador que funda essas diferenças na objetividade. Este princípio é o da estrutura da distribuição das formas de poder ou dos tipos de capital eficientes no universo social considerado

${ }^{21}$ Idem. 
- e que variam, portanto, de acordo com o lugar e os momentos. ${ }^{22}$

Bourdieu entende o espaço social como um campo, isto é, ao mesmo tempo um campo de forças, cuja necessidade se impõe aos agentes que nele se encontram envolvidos, e um campo de lutas, no interior do qual os agentes se enfrentam, com meios e fins diferenciados conforme sua posição na estrutura do campo de forças, contribuindo assim para a conservação ou a transformação de sua estrutura..$^{23}$

Essa noção dialoga com a proposição de Certeau, para quem o espaço é "um lugar praticado", produto das relações humanas e tecido por relações sociais dadas no plano do vivido, ou seja, lugar é entendido como espaço físico, social e culturalmente constituído por códigos, signos e sistemas de símbolos, constituído por redes que são tecidas em tempo e espaços específicos. ${ }^{24}$

Nessa perspectiva, entendemos a construção da sociedade dos Campos Gerais como um "espaço de relações de força" ${ }^{25}$ a partir da doação de sesmarias a determinados "homens bons", dos caminhos percorridos pelos tropeiros desde o Rio Grande do Sul até Sorocaba (SP) que propiciaram o surgimento de povoados-pousos à margem do Caminho das Tropas e que se entrecruzavam nas antigas sesmarias, enfim um espaço produto das relações humanas, construídas e justificadas, via redes de símbolos e códigos.

De forma geral, toda a estrutura social e econômica girava em torno em torno das fazendas e das relações sociais que elas propiciavam. Em grande medida, os fazendeiros dos Campos Gerais eram descendentes de primeira geração de portugueses vindos para o Brasil na primeira grande imigração peninsular do século XVIII. Estabeleceram-se como

\footnotetext{
${ }^{22}$ BOURDIEU, Pierre. Razões práticas: sobre a teoria da ação. São Paulo: Papirus, 1996, pp. 48-50.

${ }^{23} \mathrm{Idem}$

${ }^{24}$ CERTEAU, Michel. A invenção do cotidiano. 1. Artes de fazer. Petrópolis: Vozes, 1999 , p. 57.

${ }^{25}$ BOURDIEU, Pierre. Razões práticas... p. 52.
} 
comerciantes nas vilas e atuaram como militares nas guerras platinas e, posteriormente, através de matrimônios entre antigas famílias ou da aquisição de terras com capital conseguido no comércio, tornam-se fazendeiros.

A partir da Independência e com a criação da Província do Paraná em 1853, a liderança política das famílias da elite campeira institucionalizou-se na região dos Campos Gerais, em geral apoiando os presidentes da Província. Os laços patriarcais, com base no parentesco, estreitaram-se, pelas maiores exigências de relações de lealdade.

Com o tempo, os fazendeiros dos Campos Gerais passaram, ao invés de simplesmente criar o gado, a reservar invernadas em suas fazendas com o intuito de arrendá-las aos tropeiros. Era um rendimento mais rápido e mais fácil que aquele que a atividade criatória possibilitava. ${ }^{26}$

Oliveira afirma que os bens de raiz e as grandes propriedades fundiárias foram colocados de lado frente a títulos financeiros e a padrões de valor urbanos, revelando uma nova estratégia da classe dominante envolvida com o tropeirismo e as fazendas criatórias. Os grandes proprietários, nos finais do século XIX, assim, passaram a investir em outras formas de riqueza, pois para muitos deles o tropeirismo e as fazendas não mais significavam fontes de renda seguras ou garantia patrimonial consistente. Diferentemente da pecuária gaúcha que promoveria a vinculação da atividade pecuária com a existência de indústrias afins ${ }^{27}$, a facção paranaense dedicada ao tropeirismo foi obrigada a reciclar suas ativida-

\footnotetext{
${ }^{26}$ Tobias Monteiro, ao viajar ao Paraná em 1903, observou: "A tendência atual é de transformar os campos do Paraná em campos de invernagem. Ponta Grossa e Palmeira invernam já o gado de Palmas e de Guarapuava e aspiram a invernar o de Mato Grosso. No sentido próprio, a invernagem é a engorda durante o inverno do gado importado, mas o sentido desta palavra se ampliou e agora se aplica a todo o ano. O gado importado, no fim do verão, se refugia no mato, onde aumenta de valor durante o inverno, enquanto que o gado importado no fim desta estação, encontra belos campos em que engorda rapidamente. "De Rio de Janeiro au Paraná, Voyage au sud du Brésil”, Rio de Janeiro, 1903. MACHADO, Brasil Pinheiro. Três cadernos de História ..., Op. cit.,p. 82.

27 PESAVENTO, Sandra Jatahy. Pecuária e indústria. Formas de realização do capitalismo na sociedade gaúcha do século XIX. Porto Alegre: Movimento, 1986, pp. 73-75.
} 
des e abandonar um estilo de vida que lhe tinha garantido sobrevivência, riqueza e poder nos últimos duzentos anos. ${ }^{28}$ Desorganizou-se a base dos setores dominantes na região e foi alterado todo o estilo de vida característico da sociedade campeira. ${ }^{29}$

A crise econômica das fazendas dos Campos Gerais manifestou-se mais agudamente na década de 1860, arrastando-se até o final da primeira década do século XX. No periodo, algumas fazendas seriam repartidas por herdeiros que iriam viver nas cidades ou em regiões distantes, outras vendidas em retalhos para a colonização de imigrantes europeus.

A fazenda, com as estruturas que sobre ela se criaram, não cumpria mais a função de integrar uma comunidade no conjunto nacional, e logo depois, nem a de manter as grandes famílias enobrecidas dentro do contexto social da Província e do Estado. Forçosamente, portanto essa estrutura se desagregaria [...]. Filhos de fazendeiros de Ponta Grossa, Lapa e Palmeira, fixam-se nos campos de Passo Fundo, Palmeira das Missões, Soledade, Nonoai, Santa Maria, no Rio Grande. [...] Fazendas dos Campos Gerais eram vendidas à colonização russa e a companhias frigoríficas, que, afinal, também não se manteriam. [...] As novas gerações emigravam para S. Paulo, para o Rio Grande, para as cidades. ${ }^{30}$

Embora o modelo patriarcal presente nas grandes propriedades paranaenses e a própria atividade tropeira tenham sofrido retração, o prestígio auto-alimentado dos descendentes da antiga elite campeira e a cultura tropeira, ainda hoje cultuada e reinventada, deixou marcas profundas nas sociabilidades e nas percepções políticas dos habitantes dos Campos Gerais. Ao longo dos séculos XVIII, XIX e XX, a história política de Ponta Grossa tem sido marcada por seus descen-

${ }^{28}$ OLIVEIRA, Ricardo Costa de. O silêncio dos vencedores ..., Op. cit., p. 101.

${ }^{29}$ DITZEL, Carmencita de Holleben Mello. Manifestações Autoritárias ..., Op. cit., p. 40 .

${ }^{30}$ BALHANA, Altiva Pilatti, et. al. História do Paraná I. Op. cit., pp. 154-155. 
dentes ${ }^{31}$, configurando um imaginário que integra relações de mando e compadrio.

Mesmo que algumas das famílias dessa elite campeira não mais integrem o espaço local, ou tenham mudado de atividade econômica, ou mesmo representantes de outros segmentos sociais se lhe tenham incorporado por fortuna, matrimônios, orientação política ou "afinidade eletiva" 32 , a permanência desse imaginário é incontestável e ainda está presente na cidade orientando, entre outras, suas escolhas políticas.

Do ponto de vista religioso, jesuítas, beneditinos e carmelitas que se estabeleceram na região, além dos cuidados com as suas fazendas ${ }^{33}$, também se dedicavam ao atendimento espiritual e à realização de ofícios divinos junto aos moradores dos Campos Gerais. Sua presença, no entanto, parece não ter tido uma repercussão maior na religiosidade local, que centralizava as práticas devocionais em oratórios particulares e, quando a presença do sacerdote era possivel, nas missas dominicais. Saint Hilaire, quando passava por Freguesia Nova, teve esta percepção:

\footnotetext{
${ }^{31}$ É possível detectar nos nomes dos políticos que exerceram o "poder local" (prefeitos, deputados, vereadores, senadores) seu parentesco com a "elite campeira": Ernesto Villela, Victor Antonio Batista, José Miro de Freitas, Bonifácio Villela, Theodoro Batista Rosas, Flávio Carvalho Guimarães, Plauto Miró Guimarães, entre outros. Até os dias de hoje a cidade conta com um deputado estadual ligado a esse grupo, Plauto Miró Guimarães Filho, neto do senador Flávio Carvalho Guimarães e filho do ex-prefeito Plauto Miró Guimarães. DITZEL, Carmencita de Holleben Mello. Manifestações Autoritárias ..., Op. cit., p. 28.

${ }^{32}$ Löwy utiliza o conceito weberiano de "afinidade eletiva", ou seja, a possibilidade de uma relação dinâmica de atração mútua e mútuo reforço entre estruturas socioculturais diversas. LÖWY, Michel. A guerra dos deuses: religião e política na América Latina. Petrópolis: Vozes: 2000, p. 35. Não se trata de determinação causal ou jogo de influências, mas de um movimento de convergência, de uma atração recíproca, de confluências ativas entre elementos distintos.

${ }^{33}$ A primeira metade do século XVIII marcou para as ordens religiosas que trabalhavam no Brasil uma fase de grande expansão e poder econômico. Portugal acompanhava de perto as fundações dos missionários com auxílios pecuniários e dotações régias. De forma geral, essa postura da Coroa propiciou aos religiosos uma progressiva acumulação de bens em forma de grandes latifúndios e inúmeras fazendas, acrescidos por doações das autoridades locais e particulares. HOORNAERT, Eduardo; AZZI, Riolando; VAN DER GRIJP, Klaus; BROD, Benno. História da Igreja no Brasil. Primeira época. Tomo II/1. -CEHILA-Petrópolis: Paulinas/Vozes, 1992, p. 220.
} 
Era uma das doze ou quinze casas de que se compunha o lugarejo que a missa era celebrada. De acordo com o estabelecido, as dízimas iriam para as mãos do Rei e este forneceria verbas para a construção de uma igreja; já haviam sido feitos pedidos nesse sentido, mas até a época da minha viagem nada tinha sido conseguido. Por outro lado, o vigário se queixava da pouca devoção de seus paroquianos, que não concordavam em fazer o menor sacrificio em favor de sua religião. Eles não estavam habituados a cumprir qualquer ato religioso, e era a duras penas que o vigário os convencia a assistir à missa. ${ }^{34}$

Embora a religiosidade campeira causasse preocupação e provocasse questionamentos por parte de viajantes, das autoridades públicas e mesmo do clero responsável, alguns dos grandes proprietários de terra locais foram os promotores de petições feitas ao imperador Pedro I para a elevação do Bairro a Freguesia. ${ }^{35}$ A paróquia, além de espaço religioso,

${ }^{34}$ SAINT HILAIRE, Auguste de. Viagem a Curitiba e Provincia de Santa Catarina. Belo Horizonte: Itatiaia, 1978, p. 60. A cidade de Palmeira, conhecida nos seus primórdios por Freguesia Nova, foi fundada, ao que parece em 1807, e não em 1817, como conta Saint Hilaire em sua viagem, em 1820. FEDALTO, Pedro. A arquidiocese de Curitiba na sua história. Curitiba, s. e. 1958, p. 66.

${ }^{35} \mathrm{O}$ termo Freguesia pode ser entendido como comunidade paroquial. No entanto seu uso, no Brasil, tomou outros contornos. A paróquia teve, nas Constituições Primeiras do Arcebispado da Bahia, de 1707, um estatuto e um referencial para sua afirmação no Brasil do século XVIII. A Paróquia era entendida a partir do pároco, cujas funções, obrigações e competências foram estabelecidas pelas Constituições. As funções básicas centravam-se na administração dos sacramentos e seu respectivo registro, e a cura de almas. A administração dos sacramentos (especialmente casamentos e batismos) deveria ser feita no templo paroquial, ou pelo menos, que fossem registrados nos livros da paróquia. A cura de almas, o que chamamos hoje de pastoral, compreendia a pregação, a admoestação dos fregueses, o ensino da doutrina cristã, a missa dominical, os cuidados com o templo e o "remédio das necessidades dos pobres" A paróquia que surge das Constituições corresponde ao modelo desenhado por Trento, quase 200 anos antes. Trata-se de uma instituição definida pela presença permanente de um sacerdote investido da autoridade de pároco, esta entendida sob as imagens do mestre e do pai: como detentores do saber, sobre os alunos, e do poder, sobre a família. Sua autoridade era exercida dentro de uma jurisdição determinada, onde todas as manifestações de fé deveriam contar com a sua autorização. Esta autoridade, todavia, era outorgada pelo bispo, a quem o pároco estava subordinado, tendo de lhe prestar contas periodicamente. No Brasil marcado pelo padroado, coube à Igreja cumprir inúmeras funções em nome do Estado. $\mathrm{Na}$ imensidão de um território que se desdobrava a cada "entrada e bandeira", a figura da freguesia 
também era o lugar de centralização de serviços públicos, de modo que a elevação de um povoado à paróquia e freguesia representava uma conquista política:

[...] o movimento comercial do Bairro, a importância da sua colocação, centralizando várias estradas, a afluencia de moradores, a presença de fazendeiros abastados e capazes, concretisaram (sic) as aspirações dos moradores e impunham a necessidade do Bairro ser elevado a Freguesia. ${ }^{36}$

Enfim, em 15 de setembro de 1823, Ponta Grossa e Jaguariaíva passavam à condição de Freguesia por decreto imperial:

Eu, o Imperador Constitucional e Defensor Perpétuo do Império do Brasil faço saber que attendendo ao que por consulta do "Mero" (sic) de consciência e ordem ${ }^{37}$ subio a minha

$\overline{\text { preenchia a falta de autoridades e jurisdições civis, constituindo espaços que }}$ eram aos poucos ocupados pelos poderes públicos. Através do cumprimento de obrigações religiosas como o pagamento de dizimos ou as desobrigas, a autoridade colonial se fazia presente. Assim, as diversas possibilidades representadas pelas freguesias foram exploradas para a consecução de projetos coloniais, como o controle sobre os vadios, os recenseamentos, a cobrança de impostos, o recrutamento militar. Tal perfil burocrático levou a paróquia a ser o espaço para o registro de documentos com valor civil, como os testamentos, e a desenvolver atividades de contagem da população, como as listas nominativas. Funções que, além de caracterizar a paróquia como um lugar de prestação de serviços, reforçavam a imagem do pároco como autoridade. Cf. LONDOÑO, Fernando Torres. Paróquia e comunidade na representação do sagrado na Colônia. In: ___. (org.) Paróquia e comunidade no Brasil: perspectiva histórica. São Paulo: Paulus, 1997, pp. 51-90; SCHLESINGER, Hugo; PORTO, Humberto. Dicionário Enciclopédico das Religiões. Petrópolis: Vozes, v. II, 1995, verbete Paróquia.

${ }^{36}$ NOVAES, Pedro. A Fundação de Ponta Grossa. Op. cit., pp. 26-27. Os moradores do Bairro, diz o autor, não perdiam qualquer oportunidade de oferecer vantagens a todos os que passassem por ali. Um exemplo foi uma ação de fazendeiros com o objetivo de atrair os tropeiros à região e ali fazer seu pouso. João da Silva Machado (futuro Barão de Antonina), Manoel Gonçalves Guimarães, Domingos Ferreira Pinto, Antonio José Ferreira, Miguel Ferreira da Rocha Carvalhaes, Benedito Mariano Ribas, Francisco José Dias de Almeida e outros abriram uma subscrição para construir uma "Casa de Telha", com potreiro, à margem da estrada geral. Os tropeiros, satisfeitos com o abrigo oferecido, davam preferência aos moradores do Bairro.

${ }^{37} \mathrm{Embora}$ em diversas fontes consultadas apareça a forma Mero, entendemos que por problemas de grafia e de legibilidade dos documentos da época, o termo seja Mesa, em referência às Mesas de Consciência e Ordem, instituição portuguesa do século XVI, para administração política e religiosa das colônias. Era um tribunal 
Imperial presença Hei por bem crear Huma nova freguezia com o rogo de Senhora Santa Anna em hum logar visinho da Capela da telha, digo Capela denominada Casa de Telha, no bairro Ponta Grossa, distrito da villa de Castro do bispado de São Paulo, ficando desmembrada da Freguezia da mesma villa, servindo-lhe de limites o Rio Pitanguy atravessando toda a latitude do Distrito da freguezia da Villa de Castro e formando hum meio de circulo vae fazer barra no Rio Tibagy, e seguindo este até fazer barra no Rio Iapó, devendo pertencer todos os moradores além do Pitanguy e Tibagy até a barra do Iapó a esta nova freguezia, este se cumprirá como nela se contem, sendo passado pela chancelaria das ordens e valerá como carta posto que seu effeito haja de durar mais de hum anno sem embargo de ordenação em contrario sendo revestidos nos Livros da Câmara do Bispado de São Paulo nos da nova Freguezia dos que com ella confinarem. Rio de Janeiro quinze de setembro de mil oitocentos e vinte três. Segundo da Independência e do Império. Imperador com guarda. - (a) Caetano Pinto de Miranda Montenegro. ${ }^{38}$

Embora nesse documento os limites da recém-criada freguesia sejam um tanto vagos, considerando um conhecimento e uma escrita de época, pode-se dizer que o coração da Freguesia situava-se nas terras que em 1810 pertenciam a José Antonio de Oliveira, herança de sua esposa Quitéria Ângela Maria $^{39}$, e que, através de inúmeras compras, vendas, partilhas e doações, acabou, segundo consta, como o local

formado por um presidente e cinco teólogos deputados juristas. Seus despachos informativos ao rei diziam respeito a estabelecimentos de caridade, capelas, hospitais, ordens religiosas, universidades, resgates de cativos, paróquias etc. O provimento de todos os cargos eclesiásticos e os assuntos religiosos necessitavam o parecer jurídico da Mesa. Parece ter sido este o caso em questão. Cf. SCHLESINGER; PORTO. Dicionário Enciclopédico das Religiões. Op. cit., p. 1743; SOUSA, Jessie Jane Vieira de. Círculos Operários: a Igreja Católica e o mundo do trabalho no Brasil. Rio de Janeiro: Ed. UFRJ, 2002, p.103.

${ }^{38}$ NOVAES, Pedro. A fundação de Ponta Grossa. Op. cit., pp. 29-30.

${ }^{39}$ Quitéria era filha de Domingos Martins Fraga e Isabel da Costa Rosa. O destino de sua herança em terras resultou na doação de um terreno, por seu filho, o tenente Carlos José de Oliveira, para a construção da capela da freguesia, o que consta no Livro- tombo datado de 1833. 
da futura capela. Esta foi construída sob o rogo da Senhora Santa Ana ${ }^{40}$ como previa o decreto imperial. ${ }^{41}$

$\mathrm{Na}$ impossibilidade de colação imediata foi providenciado um vigário encomendado, visto que o valor da côngrua era insuficiente. ${ }^{42}$

${ }^{40}$ No Brasil português a dilatação da fé não foi apenas tarefa da Igreja, mas também da família aristocrática e patriarcal. Nela, o senhor, sempre ocupado em tarefas externas, pouco se interessava pela religião, passando à mulher branca, a "dona da casa", esse papel. Imagem dessa função atribuída à mulher branca é a de Sant'Ana, que se encontra tão freqüentemente nos engenhos e nas fazendas. Sant'Ana pode ser vista como o símbolo da casa grande ensinando o catecismo ao pessoal da senzala. HOORNAERT, Eduardo et al. História da Igreja no Brasil. Tomo II/ 1. Petrópolis: Paulinas/Vozes, 1992, p. 370.

${ }^{41}$ Os laços entre os moradores de Castro e Ponta Grossa também se manifestaram na escolha da padroeira, pois Pedro Taques de Almeida, no início do século XVIII, fez construir uma capelinha e consagrou a vasta sesmaria a esta santa. NOVAES. Pedro. A fundação da cidade de Castro. Curitiba: Gráfica Vicentina, s.d., p. 55.

${ }^{42}$ Os párocos eram escolhidos, em geral, por meio de concurso organizado pela diocese. Na existência de vaga, os candidatos eram examinados em relação ao conhecimento da doutrina e idoneidade moral. O nome selecionado era encaminhado ao governante, que deveria confirmá-lo. Quando aprovado, o pároco recebia a paróquia em caráter vitalício, isto é, perpétuo. Significava que o padre ascendia a um status diferenciado dos demais, como um dos poderes constituídos da sociedade local. Tal beneficio materializava-se no recebimento de uma dotação determinada pelo rei, a chamada côngrua. Esses vigários, denominados colados, na prática eram funcionários da coroa, favorecidos por um privilégio vitalício. Os bispos lhes concediam missão canônica, segundo a qual eles ficavam autorizados a administrar os sacramentos em sua jurisdição. Sua autoridade, tanto no plano civil quanto no religioso, era incontestável e esse privilégio era dificilmente revogado. A paróquia, do ponto de vista institucional, portanto, era a paróquia colada. Por outro lado "encomendar uma freguesia" consistia em nomear um pároco quer ad tempus. Ele era temporário e de livre remoção por ordem episcopal, não era concursado nem examinado acerca da doutrina, exigindo-se apenas idoneidade moral. O vigário encomendado era sustentado pela comunidade. Ante a precariedade do auxílio financeiro, consagrou-se a prática do "pé de altar", emolumentos pagos por batizados, casamentos e enterros. Essas contribuições eram, segundo os párocos, insuficientes para o sustento e, segundo os fregueses, uma dura carga para a sua pobreza. As paróquias encomendadas representaram, para os bispos, a possibilidade de ação autônoma, sem a intervenção do padroado, pois poderiam nomear ou mesmo remover os párocos inconvenientes. Esta situação foi muitas vezes utilizada próprios fregueses a seu favor, pois os párocos encomendados dependiam da comunidade para a manutenção pessoal e do templo e sua estabilidade no cargo. Cf. RUBERT, Arlindo. A Igreja no Brasil. v I, II, III. Santa Maria (RS): Pallotti, 1988, p. 315 et seq.; AZZI, Riolando. A cristandade colonial: um projeto autoritário. São Paulo: Paulinas, 1987. BENEDETTI, Luiz Roberto. Os santos nômades e o Deus estabelecido. São Paulo: Paulinas, 1984; LONDOÑO, Fernando Torres (org.). Paróquia e comunidade no Brasil: perspectiva 
O documento de criação da Paróquia, segundo consta, não foi encontrado:

Sobre o começo deste povoado, faltam-nos esclarecimentos precisos; bem como, não temos documento algum official sobre a creação da Parochia, que, segundo vimos de um trabalho publicado em 1880, nesta Provincia, teve logar em 15 de setembro de 1823. Fasia parte da Freguesia de Castro da qual foi desmembrada, e o seu primeiro Vigario foi o $\operatorname{Revd}^{\circ}$ Joaquim Pereira da Fonseca. Em um assento lançado por esse sacerdote no $1^{\circ}$ Livro de baptisamentos, vê-se que em 24 de dezembro de 1825, já elle era Vigario desta Freguesia e achava-se no exercicio effectivo das funcções desse cargo. ${ }^{43}$

A vila ${ }^{44}$ prosperava e crescia a população, avaliada no período em 4000 habitantes, com uma atividade econômica diversificada: a criação e comércio de animais, o fabrico de erva-mate, a exploração da madeira, e a presença de migrantes nacionais e estrangeiros eram sinais de que começava a gerar seus próprios recursos, elementos que lhe permitiram chegar às categorias de Cidade (1862) e Termo Judiciário (1865).

Os avanços políticos sincronizaram-se com alterações na estrutura social e econômica na Ponta Grossa do fim do século XIX e início do século XX. Nesse momento, "a cidade respirava um 'clima urbano': havia bandas musicais que disputavam espaço para apresentações, cinema, luz elétrica, associações beneficentes e hospital' ${ }^{\text {*45 }}$. As representações

histórica. São Paulo: Paulus, 1997, pp. 56-61; NIZZA DA SILVA, Maria Beatriz. Dicionário Histórico da Colonização Portuguesa no Brasil. Lisboa: Verbo, 1994.

${ }^{43}$ LIVRO TOMBO I da Paróquia Sant'Ana, Ponta Grossa - PR, datado de 03 de dezembro de 1886.

${ }^{44}$ Existe documentação referente à Lei $\mathrm{n}^{\circ} 34$ de 7 de abril de 1855 , quando a freguesia de Ponta Grossa foi elevada à categoria de Vila (Arquivo Público do Paraná. Oficios de Governo) que no seu art. II estabelece que os "limites com os municípios de Castro, Guarapuava e Curitiba serão os mesmos que se observam na parte eclesiástica". A Ata de Instalação da Câmara Municipal de Ponta Grossa informa sobre os limites da nova Vila. LIVRO DE ATAS. Arquivos da Câmara Municipal de Ponta Grossa (1855-1862), p. 2

${ }^{45}$ DITZEL, Carmencita de Holleben Mello. Manifestações Autoritárias ..., Op. cit., p.63. 
construídas sobre a modernização e urbanização do Paraná no advento da República geraram relatos e discursos sobre Ponta Grossa que, neles, vai assumindo "ares de cidade" ${ }^{46}$.

Flávio Carvalho Guimarães, fazendo uma releitura do mito fundador, compôs e partilhou o projeto paranista. ${ }^{47}$ Ao identificar a idéia de progresso com a concórdia e a harmonia buscou construir consensos entre a modernidade republicana e a adequação das elites às suas demandas. O acontecimento, ao ser relatado, tinha a intenção de narrar não o que se passou, mas reforçar e alimentar imageticamente uma história da fundação da cidade, ampliando o seu sentido, isto é, sugerindo subliminarmente a cada ponta-grossense daquele momento a certeza da participação, por descendência ou por ideal, da "semente de uma grande cidade, nascida e formada aos beijos da paz".

As fontes produzidas sobre a ocupação do território dos Campos Gerais, a formação e organização da sociedade local e sua condução política geraram discursos univocos, construídos com a intenção de particularizar o processo histórico, configurando uma "história oficial" de caráter épico e romântico. Tal produção contribuiu para reforçar o imaginário local que atribui aos grandes fazendeiros o papel de condutores da vida política e responsáveis pelo desenvolvimento da cidade. ${ }^{48}$

\footnotetext{
${ }^{46}$ Saint Hilaire, ao escrever sobre os Campos Gerais na primeira metade do século XIX, dizia que o quadro urbano regional era constituído por núcleos bastante modestos, onde se concentravam o comércio varejista, uma pequena burocracia, alguns artesãos e umas tantas prostitutas. SAINT HILAIRE, Auguste de. Viagem a Curitiba..., Loc. cit.

47 "O Movimento Paranista surge, portanto, no início do século, em uma Curitiba que vive a efervescência cultural propiciada pelo surto econômico da erva-mate $e$, acima de tudo, em uma época que carecia de novas representações políticas e tradições regionais, já que desaparecera a figura do Imperador que congregava em torno de si a Nação e se construíam novas identidades. Existente já no século XIX, a ideologia paranista teve, em Romário Martins, o seu principal sistematizador e divulgador no início do século XX". PEREIRA, Luis Fernando Lopes. Paranismo: cultura e imaginário no Paraná dos anos 20. In: Cultura e cidadania. Paraná, ANPUH, v. 1, pp. 273-292, 1996, p. 277.

48 DITZEL, Carmencita de Holleben Mello. Manifestações Autoritárias ..., Op. cit.,p. 60. 
"A semente de uma grande cidade":

\section{"A semente de uma grande cidade": uma leitura dos discursos construídos sobre a fundação da cidade de Ponta Grossa (PR)}

Rosângela Wosiack Zulian

Resumo: Historicamente ligada à atividade criatória, a cidade de Ponta Grossa (PR) surgiu às margens do Caminho do Viamão, o qual, a partir do século XVIII, cumpriu a finalidade de ligar São Paulo ao extremo sul do Brasil, servindo para passagem de animais levados do Rio Grande para a feira de Sorocaba. Os habitantes da região, a princípio dispersos em diversas fazendas, foram convergindo, ao longo do tempo, ao ponto central do território. A partir dos finais do século XIX, a cidade, sem perder seu tradicional aspecto campeiro, empenhou-se em ingressar no processo de modernização urbana do período. Os discursos produzidos sobre a fundação, ao tramar modernidade e tradição, "inventaram" um momento inicial, produto de um harmonioso e pacífico consenso entre os proprietários de terras, velando os conflitos subjacentes e legitimando uma versão consentânea aos interesses das elites locais.

Palavras-chave: mito fundador; discursos; espaço simbólico.

Abstract: Historically connected to cattle raising, Ponta Grossa developed along Caminho do Viamão, which, from the $18^{\text {th }}$ century on, connected São Paulo to the deep South of Brazil, being a passageway for animals driven from Rio Grande do Sul to the fair of Sorocaba. The local inhabitants, spread on several farms, would converge to its centermost point. At the end of the $19^{\text {th }}$ century, the city entered a rapid process of urban modernization. The discursive representations produced about its foundation, mixing modernity 
Rosângela Wosiack Zulian

and tradition, "invented" an initial moment, explaining pacific and consensual significations.

Keywords: foundation myth; speeches; symbolic space.

Artigo recebido para publicação em 11/11/2009

Artigo aceito para publicação em 28/11/2009 